\title{
Seasonal and inter-annual variability of the phytoplankton communities in an upwelling area of the Alborán Sea (SW Mediterranean Sea)*
}

\author{
JESÚS M. MERCADO, TEODORO RAMÍREZ, DOLORES CORTÉS, \\ MARTA SEBASTIÁN and MANOLO VARGAS-YÁÑEZ \\ Instituto Español de Oceanografía, Centro Oceanográfico de Málaga, Puerto Pesquero s/n. Apdo. 285, \\ 29640 Fuengirola, Málaga, Spain. E-mail: jesus.mercado@ma.ieo.es
}

\begin{abstract}
SUMMARY: Temporal variability (seasonal and inter-annual) in the assembly of phytoplankton communities from the northern Alborán Sea was investigated. For this purpose, the taxonomic composition of the micro- and nano-phytoplankton communities at three fixed stations was determined every three months from 1994 to 2002. A total of 357 different taxa were identified. Most of them (about 54\%) were diatom species belonging to 57 genera. Dinoflagellates and coccolitophorids accounted for 118 and 30 taxa respectively. Two time periods could be differentiated with respect to the cell abundance. Thus, the mean abundance from 1994 to 1999 was 338 cell ml$^{-1}$ and it dropped to about $60 \mathrm{cell} \mathrm{ml}^{-1}$ during the period 20002002. Diatoms and un-identified small flagellates dominated the communities during this first period, although a significant increase in the abundance of coccolitophorids occurred after 1997. Pseudo-nitzschia, Leptocylindrus and Chaetoceros were the dominant genera. In contrast, the coccolitophorids Emiliania huxleyi and Gephyrocapsa spp. quantitatively dominated the communities from 2000 to 2002 . These shifts in the community assembly were assessed by performing a sample-oriented stepwise discriminant analysis (SDA). The analysis separated the samples into three year-groups, with great inter-annual variability. In contrast, the SDA did not find any seasonal sucessional pattern. In spite of this result, chlorophyll $a$ and cell abundance tended to be higher in the spring period, which has been described for the whole Alborán basin. The nutrient concentrations in the $75 \mathrm{~m}$ upper seawater layer had inter-annual fluctuations. Thus, $\mathrm{NO}_{3}{ }^{+}+\mathrm{NO}_{2}^{-}, \mathrm{PO}_{4}^{-3}$ and $\mathrm{Si}(\mathrm{OH})_{4}$ concentrations decreased significantly in 1997-1998. Additionally, lower $\mathrm{Si}(\mathrm{OH})_{4}$ concentrations and $\mathrm{Si}: \mathrm{P}$ molar ratios were obtained in 2000. These results suggest that the inter-annual shifts in the phytoplankton taxonomic composition were due to alterations in the nutrient regime. In this paper we discuss the possible rationale for these nutrient changes.
\end{abstract}

Keywords: Alborán Sea, diatoms, dinoflagellates, inter-annual variability, phytoplankton, upwelling.

RESUMEN: CAMBIOS TEMPORALES DE LAS COMUNIDADES DE FITOPLANCTON EN EL ÁREA DE AFLORAMIENTO DEL MAR DE ALBORÁN (MAR MEDITERRÁNEO). - La variabilidad temporal de las comunidades de fitoplancton en el área norte del Mar de Alborán fue investigada. Para esto, se determinó la composición taxonómica de las fracciones micro- y pico-fitoplancton cada tres meses, desde 1994 hasta 2002, en tres estaciones situadas en la costa de Málaga. En total se identificaron 357 taxones diferentes. La mayoría de ellos (54\%) fueron diatomeas pertenecientes a 57 géneros. Se encontraron además 118 y 30 taxones de dinoflagelados y cocolitofóridos respectivamente. Los datos de abundancia de fitoplancton permitieron diferenciar dos

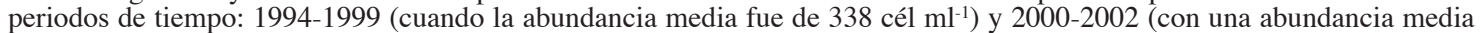

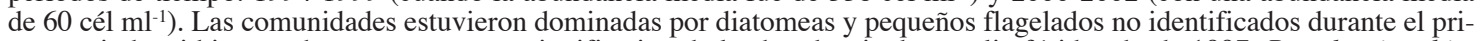
mer periodo, si bien se obtuvo un aumento significativo de la abundancia de cocolitofóridos desde 1997. Pseudo-nitzschia, Leptocylindrus and Chaetoceros fueron los géneros dominantes. Por el contrario, los cocolitofóridos Emiliania huxleyi y Gephyrocapsa spp. dominaron desde 2000 hasta 2002. Este cambio en la estructura de la comunidad fue puesto de manifiesto estadísticamente mediante un análisis discriminante (AD) orientado a muestras. El análisis ordenó las estaciones en tres grupos de años, lo que indicó una gran variabilidad interanual. En contraste, AD no permitió establecer ningún patrón de cambio estacional en las comunidades, y eso a pesar de que la clorofila $a$ y la abundancia celular tendieron a incrementarse en primavera. Las concentraciones de nutrientes en la capa de agua más superficial (de 0 a $75 \mathrm{~m}$ ) estuvieron sometidas a cambios interanuales. Así, las concentraciones de $\mathrm{NO}_{3}{ }^{-}+\mathrm{NO}_{2}^{-}, \mathrm{PO}_{4}^{-3}$ y $\mathrm{Si}(\mathrm{OH})_{4}$ tendieron a disminuir en el período 1997-

*Received June 2, 2004. Accepted February 16, 2005. 
1998. Por otro lado, las menores concentraciones de $\mathrm{Si}(\mathrm{OH})_{4}$ y de la razón molar Si:P se obtuvieron en 2000 . Estos hechos sugieren que los cambios interanuales en la estructura de la comunidad de fitoplancton fueron debidos a modificaciones del régimen de nutrientes.

Palabras clave: mar de Alborán, diatomeas, dinoflagelados, variabilidad interanual, fitoplancton, afloramiento.

\section{INTRODUCTION}

Some authors have demonstrated that changes in the relative concentration of nutrients in the Mediterranean Sea are occurring as a result of anthropogenic perturbations, such as eutrophication and climate change (UNESCO, 1988; Turley, 1999; Bethoux et al., 2002). These changes in the nutrient regime could affect the taxonomic structure of the phytoplankton communities. Bethoux et al. (2002) have suggested that the increase in phosphate and nitrate relative to silicate concentrations could produce a shift from a diatom-dominated ecosystem to a non-siliceous algal dominated ecosystem. An increase in the number of phytoplankton blooms that occur (Moncheva et al., 2001), could also be expected in the Mediterranean coastal areas. However, there is little data available for testing these hypothesis since almost all the phytoplankton studies in the Mediterranean Sea have focused on bulk measurements of the biomass based on estimations of the pigment composition and/or particulate organic carbon (Rodríguez et al., 1997, Vidussi et al., 2001, Echevarría et al., 2002, Jacquet et al., 2002, Marty et al., 2002, Reul et al., 2002). Only a few studies that describe the taxonomic structure of the communities are available (Margalef 1969, Delgado 1990, Claustre et al., 1994, Fiala et al., 1994, Videau et al., 1994, Solic et al., 1997), and therefore its long-term variability is still unknown.

The Alborán Sea (the westernmost basin in the Mediterranean) is an example of this limited information about the phytoplankton community assembly. In contrast, the hydrodynamic of this basin is well-known (Parrilla and Kinder, 1987). The Atlantic seawater influx through the Strait of Gibraltar produces a system with two anticyclonic gyres which occupy almost the entire central part of the basin. This Atlantic seawater jet produces an intensive geostrophyc front in the north-western sector of the Alborán Sea (Parrilla and Kinder, 1987; Sarhan et al., 2000). This causes the upwelling of deeper Mediterranean water, which is rich in inorganic nutrients, off the Málaga coast. This coast is one of the most productive areas in the western Mediterranean Sea. Various papers have demonstrated that chlorophyll $a$ follows a coinciding spa- tial distribution pattern with nutrients (Cortés et al., 1985; Minas et al., 1991; Rodríguez et al., 1997). Additionally, satellite images have demonstrated that chlorophyll $a$ concentration in the whole basin has two-yearly regimes (García-Górriz and Carr, 2001), according to the de-stratification of the water column from November to March and its thermal stratification in the summer period. However, the intensity of the upwelling in the north-western sector of the Alborán Sea is often increased by the local winds, and in this case the yearly pattern is often not established. Some attempts have been carried out to taxonomically describe the structure of the phytoplankton communities in this upwelling zone (Balle, 1963; Margalef, 1969; Delgado, 1990). According to the published data, the phytoplankton community is dominated by small flagellates and diatoms while the abundance of dinoflagellates is very low (Delgado, 1990). However, these reports are based on single oceanographic surveys and therefore the possible temporal patterns and/or seasonal cycles have not yet been described.

The Spanish Institute of Oceanography (IEO) has supported an environmental monitoring programme on the northern coast of the Alborán Sea since 1992 (Camiñas et al., 1998; Vargas-Yánez et al., 2002). Information about physical and biological variables (including taxonomic composition of the phytoplankton communities) is generated every three months. The objective of this paper is to analyse the available data series from October 1994 to April 2002 to investigate patterns of temporal change in the phytoplankton communities (including seasonal cycles). For this proposal, raw data on species abundance were analysed with a stepwise discriminant analysis (SDA). Functional key groups of phytoplankton were detected using a cluster analysis. The possible relationship between the phytoplankton successional patterns and the changes in nutrient regimen was examined.

\section{MATERIAL AND METHODS}

Water samples were collected at three different stations located on the continental shelf off the Málaga coast (st. 1, st. 2 and st. 3, Fig. 1). Surveys 


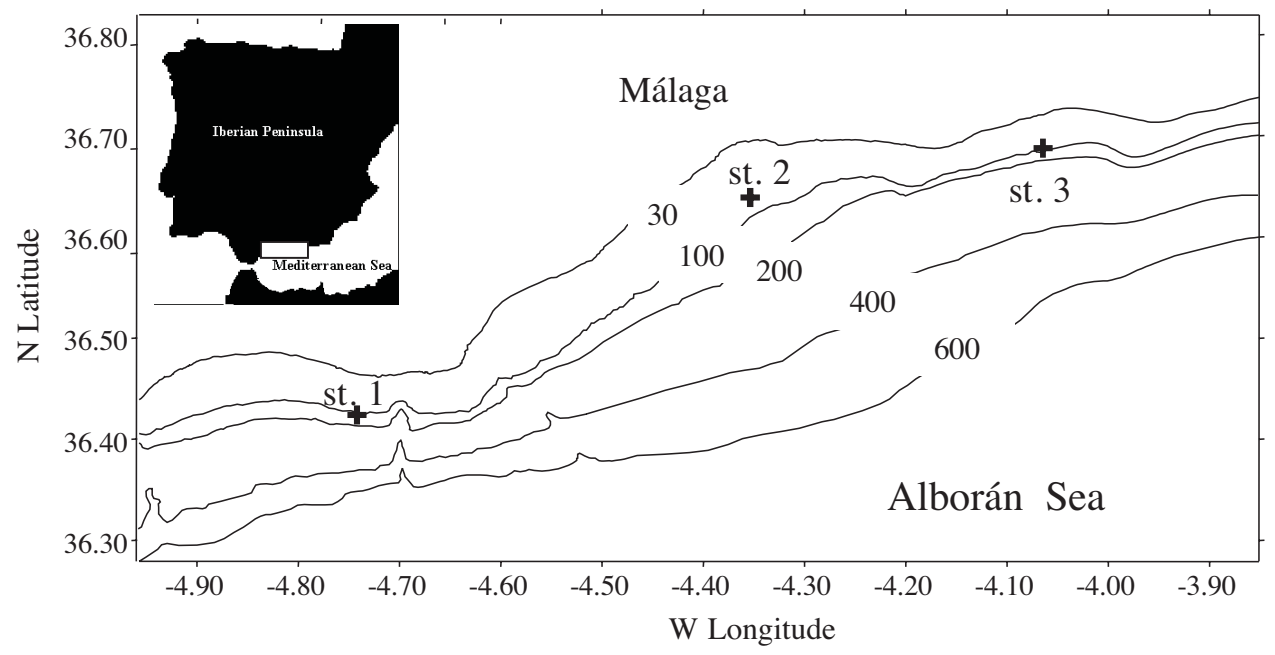

FIG. 1.- Location of the stations sampled.

were carried out on board RV 'Odón de Buen' starting in October 1994 in station 1 and in October 1997 in stations 2 and 3. Four surveys were performed each year in order to describe the patterns of seasonal variability. The surveys were performed in February (winter period), March (spring period), July (summer period) and October (autumn period). However, these dates often had to be modified according to the availability of the RV and/or sea conditions (winds and storms). Vertical profiles of temperature, salinity and fluorescence were obtained with a Seabird 25 CTD at each station. Water samples for determining the phytoplankton community taxonomic composition were collected with $5 \mathrm{~L}$ Niskin bottles at $0.4,1.3$ and 2.7 times the Secchi disc depth. These depths indicate where there is $50 \%, 10 \%$ and $1 \%$ of surface irradiance respectively. In each station, the vertical profile of chlorophyll $a$ fluorescence was used to assure that one of the samples was collected at a depth matching the fluorescence maximum signal depth. $500 \mathrm{ml}$ of the sample were preserved in bottles and fixed with $4 \%$ formaldehyde solution. The formaldehyde solution buffered with disodium tetraborate (borax) was made prior to each survey. Additionally, two litres of seawater were filtered through a glass fibre filter (Wathman GF/F) and frozen at $-20^{\circ} \mathrm{C}$ to determine the chlorophyll $a$ concentration. Chlorophyll $a$ was estimated from the pigment extract obtained in acetone using trichromatic equations (SCOR-UNESCO 1966). $10 \mathrm{ml}$ aliquots of seawater were also frozen immediately in order to determine the nutrient concentrations (nitrate, nitrite, phosphate and silicate) by means of a Technicon Autoanalyser (Traacs 800, Bran Luebbe, Nortedstedt, Alemania).
A total of 186 samples were collected throughout the study period. All the samples were analysed within 10 months of being collected. Although the analyses were done over several years, they were performed by the same laboratory. The taxonomic composition of the phytoplankton communities in each sample was determined following the sedimentation technique developed by Utermöhl (Utermöhl, 1958). $100 \mathrm{ml}$ of the fixed sample were sedimented in a chamber for $48 \mathrm{~h}$. For samples in which a low cell concentration could be expected due to their chlorophyll $a$ concentration, $200 \mathrm{ml}$ were sedimented during $72 \mathrm{~h}$ (i.e. about 2 hours per $\mathrm{cm}$ in height of the water column). The samples were analysed using a Leica inverted microscope. A sufficient number of fields were counted at $400 \mathrm{x}$ magnification until at least 100 individuals of the most abundant species were registered (Ros and Miracle, 1984). $1000 \mathrm{x}$ magnification was used when required for identification. The bottom of the chamber was then scanned in order to register the larger species. The smallest size limit for microflagellates according to the Utermöhl technique was approx. 2 $\mu \mathrm{m}$, therefore the picoplankton fraction was not quantified in this study. Scanning electron microscopy was used to asses the taxonomic determinations of phytoplankton cells smaller than 10 $\mu \mathrm{m}$ (coscinodiscaceae, some pennate diatoms, coccolitophorids and silicoflagellates). A critical point drying technique was used (Cohen, 1974). Thus, $250 \mathrm{ml}$ were filtered through $0.4 \mu \mathrm{m}$ Nucleopore filters. The filters were mounted, air-dried and coated with gold. The species nomenclature was validated following the recommendations published in Tomas (1997). 
A sample-oriented stepwise discriminant analysis (SDA) was performed to detect patterns of temporal change in the phytoplankton communities (Cooley and Lohnes, 1971; Allen and Skagen, 1973; Karenzt and Smayda, 1998). The raw abundance data matrix was transformed logarithmically according to $\log \left(n_{i, j}+1\right)$, where $n_{i}$ is the abundance of the $i$ species in the $\mathrm{j}$ sample. Additionally, the transformed matrix was simplified by considering only the species which were present in more than $10 \%$ of the samples (Karentz and Smayda 1998). Two different ways of grouping species were assayed by SDA according to two different criteria: year groups to examine annual successional patterns (a complete annual cycle was considered to be from October to September) and seasonal groups to examine seasonal changes. The seasonal groups were established according to the time period of the year in which a particular sample was collected. The following seasons were defined: spring (from April to June), summer (July-September), autumn (October-December) and winter (January-March). For this seasonal comparison, a community mean composition for each survey was calculated from the data obtained for the three stations. Additionally, a species-oriented cluster analysis (CA) was performed in order to detect key functional groups. The Pearson correlation coefficient matrix was used as the similarity matrix. It was constructed from the logarithmically transformed species abundance matrix of the 30 most frequent species. Ward's method was used as the linkage procedure (Ward, 1963).

In order to determine possible seasonal patterns in the measured quantitative variables, a one-way analysis of variance (ANOVA) followed by a Tukey test (Sokal and Rohlf, 1981) was applied. For this proposal, the data from each station were grouped seasonally as mentioned above. Average values of the surface layer (from the surface to $50 \mathrm{~m}$ depth) were used for this analysis. A mean value of the variables was produced for each survey since the differences found between stations were statistically nonsignificant (data not shown). The mixed-layer depth was estimated as the depth for which the density gradient from the surface was 0.5 . A correspondence analysis was then performed (Ter Braak and Prenctice, 1988). The logarithmically transformed matrix of the 30 most abundant species was compared with the suite of environmental variables mentioned above. All the samples were included in this analysis. Additionally, the main patterns of year-toyear changes in nutrients were examined using aver- age figures for the overall studied area. Thus, a nutrient concentration integrated value in the upper seawater layer (up $75 \mathrm{~m}$ depth) was calculated for each survey. The integration was performed using the trapezoidal method.

Values of the variables are presented as the mean \pm 1 standard error. All the statistical analyses were performed using the software STATISTICA '99 Edition (Stat. Soft., Inc.).

\section{RESULTS}

\section{Taxonomic characterization and cell abundance}

The Secchi disc depth was an average of $10.7 \pm 1.0 \mathrm{~m}$ during the whole study period, with a maximum value of $26 \mathrm{~m}$ in February 1998 at station 2 . Therefore, all the samples analysed were collected within the upper $70 \mathrm{~m}$ seawater layer. The vertical maximum of fluorescence was within this layer in all the surveys. A phytoplankton sample was collected at this depth level (or very close). Therefore, it can be assumed that the phytoplankton composition obtained in each station is representative of the whole community (within the micro- and nanoplankton size range) inhabiting the photic zone during each survey.

A total of 357 different taxa were identified in this study. Most of the taxa (about 54\%) were diatom species belonging to 57 genera. The most representative diatom genera were Chaetoceros and Nitzschia with 24 and 17 species respectively. Dinoflagellates were the second largest group with respect to the total number of taxa identified (118 species were identified). Protoperidinium, with 32 species, was the most represented genus of this group. Thirty-one species of coccolitophorids belonging to 23 different genera were also identified. Other genera of Chlorophyceae, Cryptophyceae, Chrysophyceae, Euglenophyceae and Raphidophyceae were found in the samples.

Only 43 taxa were found in more than $10 \%$ of the samples (Table 1). Most of the taxa were diatoms followed by dinoflagellates, although it was a coccolitophorid, Emiliania huxley, that was the species that appeared most frequently during the study. Only a genus belonging to another different group (Cryptomonas) was present in more than $10 \%$ of the samples. The presence of un-identified small flagellates (smaller than $10 \mu \mathrm{m}$ ) was also common; they appeared in more than $50 \%$ of the samples. 
TABLE 1. - Most frequent taxa found in the study area. $\mathrm{n}$ indicates the absolute frequency of the taxa with respect to the total sample number analysed in each station (84, 52 and 50 for stations 1, 2 and 3 respectively). Mean abundance over the overall study time is also presented (the number in the brackets indicates 1 standard error).

\begin{tabular}{|c|c|c|c|c|c|c|}
\hline & \multicolumn{2}{|c|}{ St 1} & \multicolumn{2}{|c|}{ St 2} & \multicolumn{2}{|r|}{ St 3} \\
\hline & $\mathrm{n}$ & cells $\mathrm{ml}^{-1}$ & $\mathrm{n}$ & cells $\mathrm{ml}^{-1}$ & $\mathrm{n}$ & cells ml-1 \\
\hline \multicolumn{7}{|l|}{ Diatoms } \\
\hline Asterionellopsis glacialis (Castracane) Round & 26 & $39.3(10.7)$ & 8 & $69.2(40.9)$ & 4 & $48.6(39.9)$ \\
\hline Chaetoceros affinis Lauder & 11 & $7.3(2.2)$ & 6 & $10.5(7.7)$ & 3 & $25.4(15.9)$ \\
\hline Chaetoceros decipiens Cleve & 14 & $5.4(2.4)$ & 4 & $1.7(0.4)$ & 2 & $1.2(0.7)$ \\
\hline Chaetoceros didymus Ehrenberg & 18 & $18.4(5.7)$ & 2 & $9.6(1.0)$ & 2 & $22.7(7.0)$ \\
\hline Chaetoceros lorenzianus Grunow & 15 & $6.4(1.2)$ & 3 & $43.2(24.2)$ & 6 & $38.0(16.8)$ \\
\hline Cocconeis placentula Ehrenberg & 13 & $1.5(0.5)$ & 4 & $0.9(0.2)$ & 6 & $0.6(0.1)$ \\
\hline Cyclostephanos dubius (Fricke) Round & 8 & $1.0(0.12)$ & 6 & $1.4(0.4)$ & 5 & $2.0(0.7)$ \\
\hline Cyclotella $\mathrm{sp}$ & 4 & $25.7(24.8)$ & 6 & $1.2(0.3)$ & 9 & $1.4(0.3)$ \\
\hline Cylindrotheca closterium (Ehrenberg) Reimann \& Lewin & 24 & $13.5(4.3)$ & 5 & $0.7(0.1)$ & 5 & $4.6(3.8)$ \\
\hline Dactyliosolen fragilissimus (Bergon) Hasle & 31 & $10.7(2.0)$ & 8 & $5.7(1.8)$ & 9 & $8.9(4.2)$ \\
\hline Dictyocha fibula Ehrenberg & 18 & $25.7(24.8)$ & 13 & $2.8(1.7)$ & 8 & $0.9(0.2)$ \\
\hline Ditylum brightwellii Grunow & 12 & $7.3(4.0)$ & 8 & $1.7(0.6)$ & 4 & $5.1(2.1)$ \\
\hline Eucampia cornuta (Cleve) Grunow & 11 & $8.1(5.4)$ & 3 & $4.2(3.3)$ & 5 & $7.0(4.9)$ \\
\hline Guinardia striata (Stolterfoth) Peragallo & 26 & $11.3(5.6)$ & 6 & $5.0(2.4)$ & 4 & $11.9(9.1)$ \\
\hline Hemiaulus sinensis Greville & 16 & $4.1(1.3)$ & 6 & $2.3(0.9)$ & 2 & $7.8(3.8)$ \\
\hline Lauderia annulata Cleve & 16 & $13.0(4.7)$ & 4 & $16.9(9.7)$ & 5 & $4.0(1.7)$ \\
\hline Leptocylindrus danicus Cleve & 41 & $24.7(7.0)$ & 17 & $15.5(3.8)$ & 7 & $4.0(1.7)$ \\
\hline Lioloma pacificum (Cupp) Hasle & 15 & $1.8(0.3)$ & 3 & $2.3(1.1)$ & 3 & $1.1(0.4)$ \\
\hline Nitzschia longissima genuina (Brébisson, in Kützing) Ralfs in Pritchard & 46 & $3.3(0.4)$ & 19 & $2.2(0.6)$ & 10 & $2.8(0.7)$ \\
\hline Pseudo-nitzschia delicatissima (Cleve) Heiden in Heiden \& Kolbe & 29 & $10.2(2.0)$ & 10 & $18.1(16.5)$ & 9 & $1.7(0.8)$ \\
\hline Pseudo-nitzschia fraudulenta (Cleve) Hasle & 7 & $8.1(1.4)$ & 9 & $2.6(0.6)$ & 6 & $1.9(0.8)$ \\
\hline Pseudo-nitzschia cf pungens (Grunow ex Cleve) Hasle & 49 & $41.5(7.2)$ & 27 & $15.3(4.6)$ & 17 & $20.3(8.6)$ \\
\hline Rhizosolenia delicatula Cleve & 20 & $7.9(2.3)$ & 12 & $3.5(1.2)$ & 10 & $2.4(0.5)$ \\
\hline Rhizosolenia styliformis Brightwell & 8 & $3.3(1.8)$ & 6 & $2.3(0.7)$ & 5 & $1.3(0.3)$ \\
\hline Skeletonema costatum (Greville) Cleve & 26 & $23.0(6.5)$ & 4 & $15.5(2.5)$ & 3 & $44.6(30.1)$ \\
\hline Thalassionema nitzschioides (Shuette \& Schrader) Hasle & 18 & $24.1(7.9)$ & 16 & $4.1(0.9)$ & 6 & $11.3(9.4)$ \\
\hline Thalassiosira decipiens Grunow & 26 & $50.3(21.2)$ & 11 & $13.3(5.6)$ & 8 & $9.4(3.4)$ \\
\hline Thalassiosira spp. Grunow & 43 & $25.4(11.5)$ & 24 & $11.1(6.1)$ & 11 & $10.1(4.9)$ \\
\hline \multicolumn{7}{|l|}{ Dinoflagellates } \\
\hline Alexandrium sp. & 22 & $3.9(1.2)$ & 14 & $4.2(1.6)$ & 14 & $2.2(0.5)$ \\
\hline Gymnodinium sp. & 18 & $3.1(1.3)$ & 10 & $3.7(2.5)$ & 6 & $0.9(0.1)$ \\
\hline Oxytoxum variabile Schiller & 10 & $1.0(0.1)$ & 5 & $0.8(0.1)$ & 6 & $0.9(0.2)$ \\
\hline Proboscia alata (Brightwell) Sundström & 28 & $3.8(0.6)$ & 12 & $1.7(0.3)$ & 8 & $3.1(0.9)$ \\
\hline Prorocentrum minimum (Pavillard) Schiller & 19 & $1.7(0.4)$ & 8 & $5.7(3.1)$ & 6 & $0.7(0.1)$ \\
\hline Prorocentrum balticum (Lohmann) Abe & 9 & $1.3(0.4)$ & 12 & $0.8(0.1)$ & 11 & $0.7(0.1)$ \\
\hline Prorocentrum compressum (Bailey) Abe & 12 & $1.1(0.2)$ & 9 & $0.6(0.1)$ & 10 & $0.8(0.1)$ \\
\hline Prorocentrum micans Ehrenberg & 7 & $1.6(0.4)$ & 8 & $3.6(2.9)$ & 5 & $1.2(0.3)$ \\
\hline Prorocentrum rotundatum Schiller & 24 & $2.0(0.3)$ & 13 & $2.7(1.8)$ & 5 & $5.4(4.6)$ \\
\hline Protoperidinium depressum (Bailey) Balech & 13 & $1.2(0.2)$ & 4 & $1.0(0.3)$ & 3 & $1.5(1.1)$ \\
\hline Scrippsiella trochoidea (Stein) Loeblich & 17 & $2.1(0.5)$ & 15 & $1.3(0.4)$ & 15 & $2.1(0.6)$ \\
\hline \multicolumn{7}{|l|}{ Coccolitophorids } \\
\hline Calcidiscus leptoporus (Murray \& Blackman) Loeblich \& Tappan & 15 & $1.2(0.2)$ & 11 & $0.6(0.1)$ & 13 & $1.2(0.4)$ \\
\hline Coronosphaera mediterranea (Lohmann) Gaarder & 16 & $3.6(1.2)$ & 9 & $1.9(1.1)$ & 8 & $1.4(0.4)$ \\
\hline Gephyrocapsa ericsonii McIntyre \& Bé & 12 & $16.1(5.1)$ & 7 & $4.4(2.1)$ & 10 & $8.7(2.6)$ \\
\hline Gephyrocapsa oceanica Kamptner & 28 & $7.1(2.8)$ & 23 & $10.8(6.0)$ & 22 & $4.2(2.0)$ \\
\hline Emiliania huxleyi (Lohmann) Hay \& Mohler & 41 & $19.1(3.6)$ & 32 & $17.9(6.0)$ & 28 & $18.7(3.7)$ \\
\hline Ophiaster hydroideus (Lohmann) Lohmann & 11 & $5.5(0.4)$ & 8 & $3.7(2.5)$ & 3 & $1.3(0.4)$ \\
\hline Syracosphaera pulchra Lohmann & 10 & $1.3(0.2)$ & 6 & $1.2(0.4)$ & 8 & $0.7(0.1)$ \\
\hline \multicolumn{7}{|l|}{ Cryptophycceans } \\
\hline Cryptomonas spp. & 21 & $4.6(1.6)$ & 17 & $1.5(0.4)$ & 11 & $0.8(0.1)$ \\
\hline
\end{tabular}

The cell mean abundances of each station for all the analysed time periods were $251 \pm 42,190 \pm 38$ and $155 \pm 43$ cells ml-1 (stations 1,2 and 3 respectively). The high standard error values of the means are indicative of a strong variability (Fig. 2). Thus, the highest cell abundance was obtained in April 1999 with around 1500 cells $\mathrm{ml}^{-1}$ in the three stations. In contrast, values that were 25 fold lower were obtained during 2001 when the lowest cell abundance value was registered in the three stations (less than 35 cells ml$^{-1}$ ). High variability of the cell abundance was also found when examining the temporal distribution of the four main groups of phytoplankton, including the un-identified small flagellate group (Fig. 3, note the different y axis scales). In general, the temporal distribution of the cell abun- 


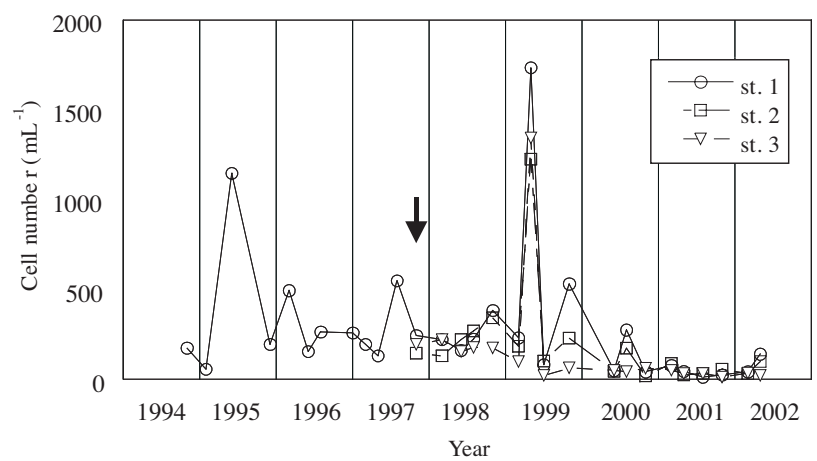

FIG. 2. - Temporal evolution of the total cell abundance determined at the tree sampled stations. The points represent the mean value of the water column analysed in each survey. The vertical arrow indicates the start of sampling in stations 2 and 3.

dance between these four groups was very similar in the three stations. Thus, peaks of diatoms (cell numbers up to 1000 cells $\mathrm{ml}^{-1}$ ) were observed in May 1995 and April 1999. These peaks (Fig. 3a) tempo-

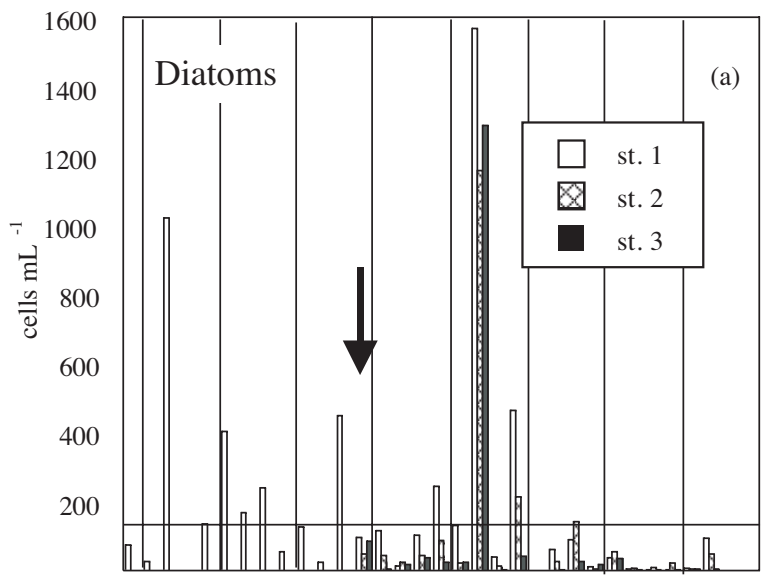

$\begin{array}{llllllll}95 & 96 & 97 & 98 & 99 & 00 & 01 & 02\end{array}$

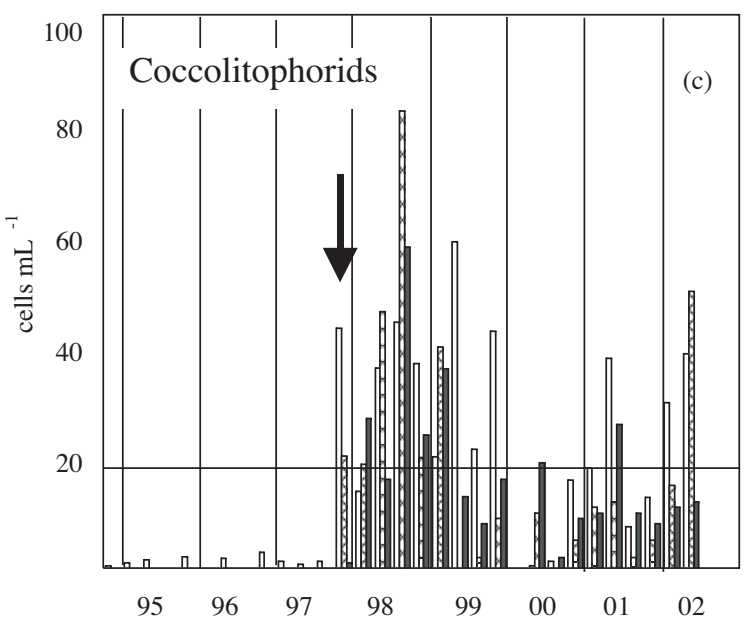

rally coincided with the maximum cell abundance (May 1995 and April 1999, Fig. 2), which indicates that this group was responsible for the high phytoplankton biomass values at the three stations. In fact, there was a strong significant correlation $\left(\mathrm{R}^{2}=0.94\right.$, $\mathrm{p}<0.01)$ between diatom abundance and total abundance of cells at the three stations. The dominant species during the diatom peak that occurred in May 1995 were Thalassiosira decipiens and Pseudo-nitszchia cf pungens. In contrast, the peak that occurred in April 1999 was mainly due to the massive presence of Chaetoceros sp. cells at the three stations (this species accounted for approximately $55 \%$ of all the diatom cells registered at that moment). It is interesting to note that diatom abundance dropped drastically during 2001 at the three stations. There were two clearly differentiated time periods with respect to the distribution of un-identified small flagellates (Fig. 3b): from October 1994
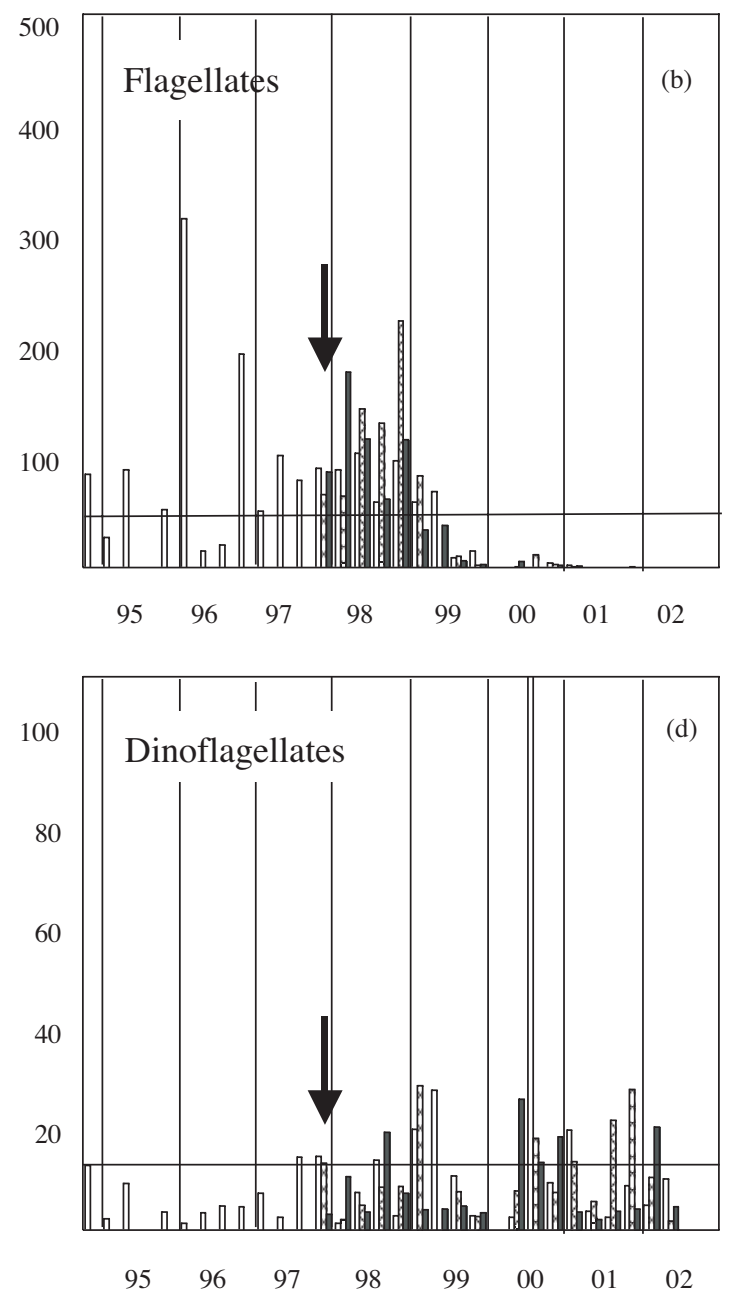

FIG. 3. - Cell abundance of the four main groups of phytoplankton at the three stations sampled. The horizontal line indicates the mean abundance through the entire study period. Note that the y-axis scales are different. The vertical arrows indicate the start of sampling in stations 2 and 3. 


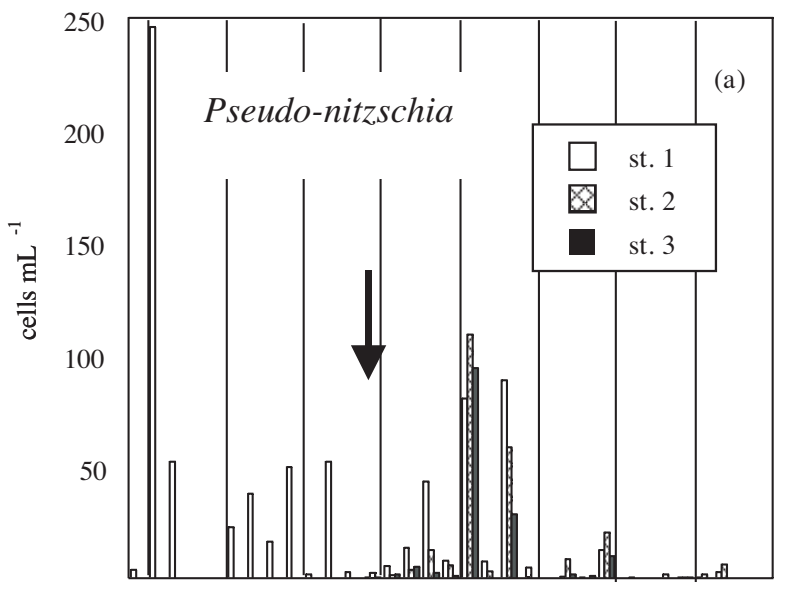

$\begin{array}{llllllll}95 & 96 & 97 & 98 & 99 & 00 & 01 & 02\end{array}$

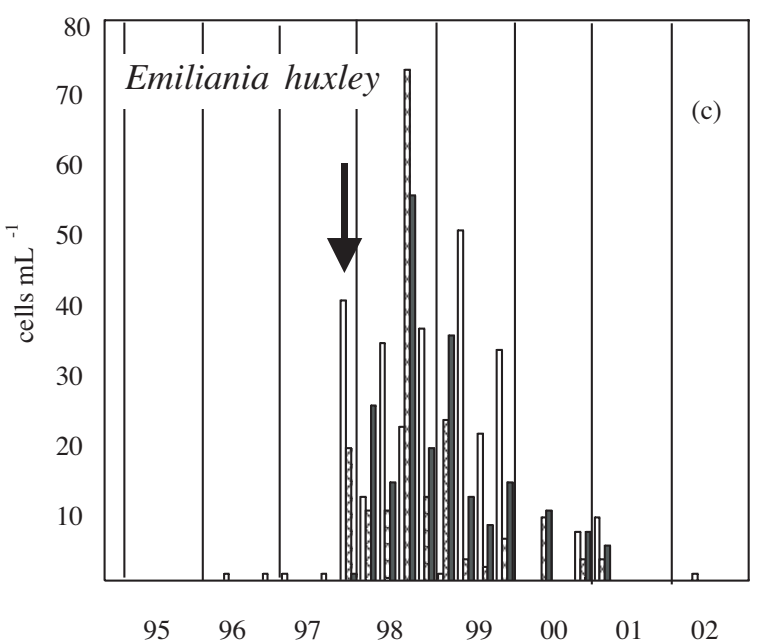

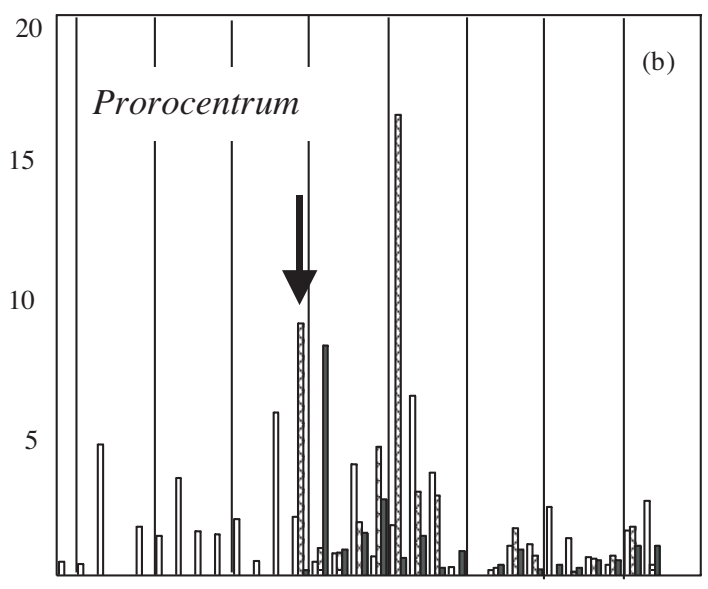

$\begin{array}{llllllll}95 & 96 & 97 & 98 & 99 & 00 & 01 & 02\end{array}$

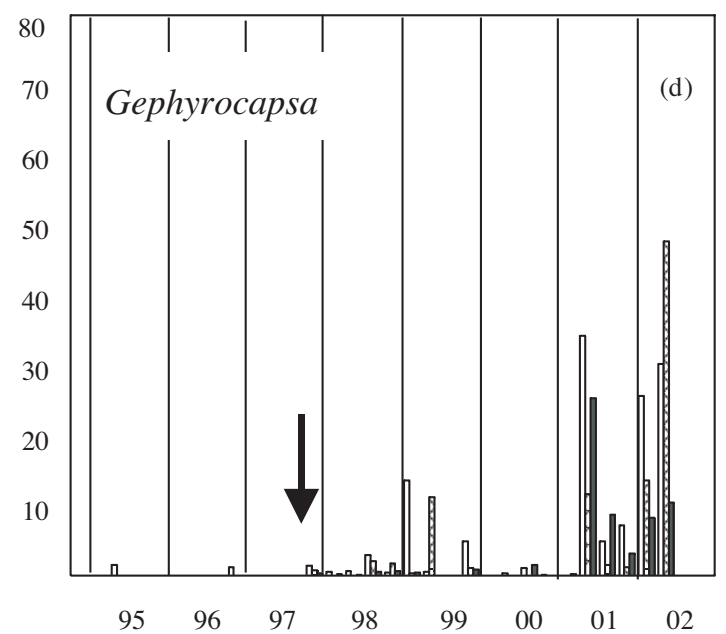

FIG. 4. - Cell abundance of four representative genera at the three stations sampled. Note that the y-axis scales are different. The vertical arrows indicate the start of sampling in stations 2 and 3.

to April 1999 their abundance remained roughly constant $\left(76 \pm 8\right.$ cells $\left.\mathrm{ml}^{-1}\right)$, and from June 1999 to April 2002 it decreased drastically (mean abundance of $2.4 \pm 0.4$ cells $\mathrm{ml}^{-1}$ ). This temporal distribution pattern was almost the opposite of the pattern found for the coccolitophorids (Fig. 3c). Coccolitophorid abundance was low from October 1994 to 1997 (6.1 \pm 2.7 cells $\mathrm{ml}^{-1}$ ) and comparatively high afterwards $\left(21 \pm 2.2\right.$ cells $\left.\mathrm{ml}^{-1}\right)$. Dinoflagellates (Fig. $3 \mathrm{~d}$ ) had the most regular temporal distribution pattern with a mean abundance of $12 \pm 2.9$ cells $\mathrm{ml}^{-1}$. The highest dinoflagellate peak was found in October 2000 at station 1 and Gymnodinium catenatum was the most representative species. Diatoms and/or un-identified small flagellates quantitatively dominated the communities at the three stations from 1994 to 2000. In contrast, dinoflagelates and/or coccolitophorids were more abundant than diatoms and un-identified small flagellates during 2001. Dinoflagellates dominated the phytoplankton community only once in station 1 and three times in stations 2 and 3 from May 2000 to February 2002.

Figure 4 shows the temporal distribution of the more frequent genera (Pseudo-nitzschia, Prorocentrum, Emiliania and Gephyrocapsa). Pseudonitzschia was the most abundant diatom genus on several occasions from 1994 to 1999. Its abundance remained roughly constant during this period (with the exception of the peak reached in February 1995). It decreased to lower than 5 cells ml ${ }^{-1}$ during 20002002. Other diatom genera (e.g. Nitzschia and Chaetoceros) followed a similar temporal distribution pattern (data not shown). Prorocentrum was present for a lot of the studied time period, with a mean abundance of 1.9 cells $\mathrm{ml}^{-1}$. Higher values were found during 1998 and 1999, especially at station 2 where a value of 15 cells mll ${ }^{-1}$ was obtained in February 1999. The distribution of the coccolitophorids Emiliania and Gephyrocapsa was more irregular. Both genera were almost absent from 1994 


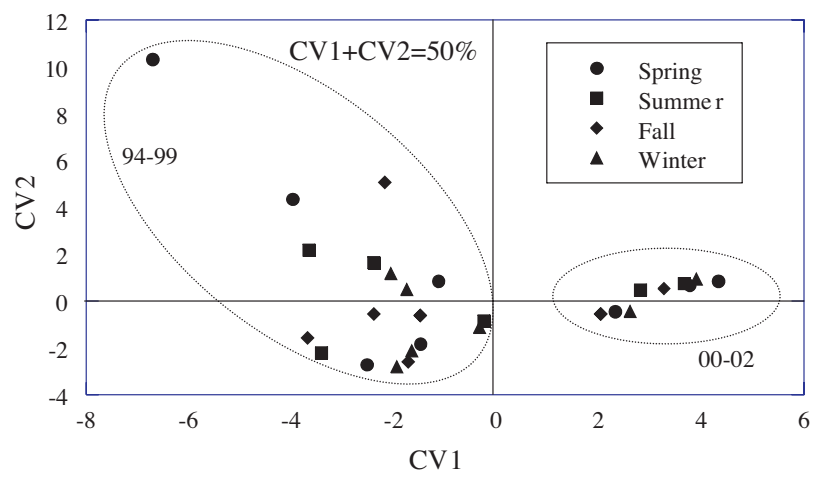

FIG. 5. - Canonical variables 1 (CV1) and 2 (CV2) of the stepwise discriminant analysis for the seasonal groups. The 30 most abundant species were used in the analysis. The points represent the mean values from the three stations in each survey.

to 1997 but their abundances increased afterwards. Emiliania huxleyi was the most abundant species on several occasions at the three stations from 1998 to 2000. Its mean abundance increased significantly during this period (22 cells ml-1 as compared to 2 cells $\mathrm{ml}^{-1}$ previously registered). The highest cell abundances of Gephyrocapsa were obtained during 2001 and 2002 when it was the most abundant species on several occasions. Its mean abundance was 16 cells $\mathrm{ml}^{-1}$ during this period.

\section{Seasonal and inter-annual variability}

A SDA was performed using the taxonomic composition data obtained at each depth and survey grouped according to a seasonal criterion. Averaged data from the three stations were used for this analysis. Figure 5 shows the values of the two first components of variance for each seasonal group. A segregation of the groups along CV1 and CV2 and two clusters were generated. One of the two clusters was correlated positively to CV1 and comprised all the seasonal groups belonging to the 1994-1999 time period irrespective of the seasonal regime. The other cluster was correlated negatively to CV1 and comprised the groups belonging to the years from 2000 to 2002. The distribution of the groups did not correspond to the seasonal grouping criterion since seasonal groups were placed along the axes irrespectively. This result indicates that there was no clear seasonal sucessional pattern in the community structure. The results of the other model evaluated using a SDA to investigate annual patterns (OctoberSeptember) are shown in Figure 6. They coincide basically with the ones obtained using the seasonal grouping criterion. Thus, the year-groups were segregated along $\mathrm{CV} 1$ and $\mathrm{CV} 2$ into three clusters. Two

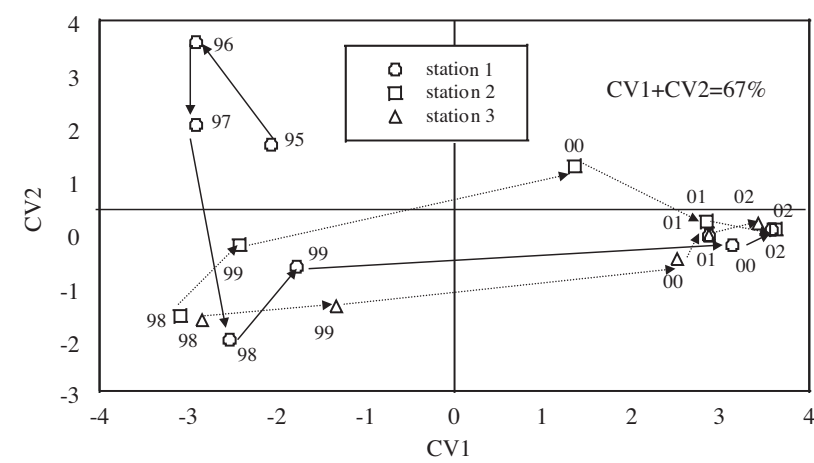

FIG. 6. - Canonical variables 1 (CV1) and 2 (CV2) of the stepwise discriminant analysis for yearly groups. The 30 most abundant species were used in the analysis.

clusters consisted of 1995-1997 and 1998-1999 year-groups and were negatively correlated to CV1. The 1995-1997 year cluster was positively correlated to CV2. In contrast, the 1998-1999 cluster was negatively correlated to this axis. 2000-2002 yeargroups were closely related to a third cluster which was positively correlated to CV1. It is interesting to note that the year-groups related to each other strongly in spite of the station, which indicates that the differences in the phytoplankton community structure between stations were less significant than the changes that occurred inter-annually. The results of the SDA indicate that significant taxonomic shifts occurred in the three stations in 1997 and during the 1999-2000 time period.

In order to identify the structure of the communities in the three year groups obtained by the SDA, a species-oriented cluster analysis (CA) was performed. For this purpose, a matrix with the mean abundances for the water column for each survey and station was constructed. Figure 7 shows the results obtained by using the 30 most abundant species. Similar results were obtained when the 20 and 40 most abundant species were considered (data not shown). Cluster 1 (branch I) mainly comprised diatoms and the dinoflagellates Scripsiella trochidea, Protoperidinium depressum and Prorocentrum minimum. Cluster 2 can be divided into two subgroups (according to the two main branches obtained): Branch II included the coccolitophorids Gephyrocapsa ericsonii, Gephyrocapsa oceanica, Coronosphaera mediterranea and Calcidiscus leptoporus and the dinoflagellate Prorocentrum compressum. Branch III comprised the coccolitophorid Emiliania huxleyi (the most frequent species) and the small un-identified flagellates. Other diatoms and dinoflagellates were also grouped in this branch. 


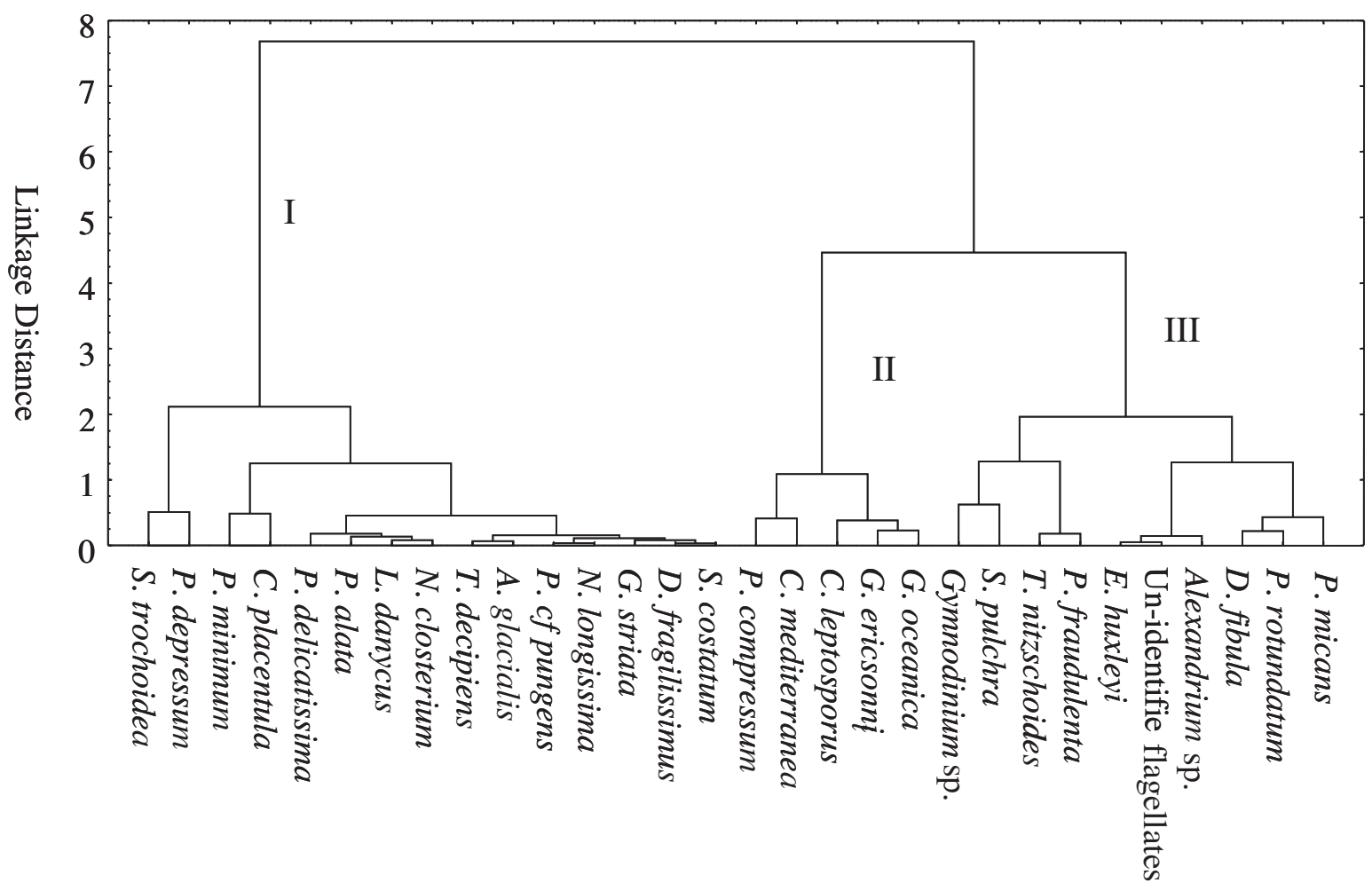

FIG. 7. - Results of the species-oriented cluster analysis. The 30 most abundant species were used in the analysis. Ward's method was used as the linkage procedure. The numbers indicate the main branches detected.

\section{Hydrological and chemical variables}

Table 2 shows the seasonal mean values of the different physical, chemical and biological variables which characterised the upper seawater layer of the water column (from the surface to $50 \mathrm{~m}$ depth) at the three stations. All the values were analysed jointly since there were no significant differences between stations for any variable (data not shown; an exhaus- tive analysis of these data is presented elsewhere). The inter-seasonal differences in the mean surface temperature were significant, which indicates that there is a seasonal cycle with higher temperatures in summer and lower ones in winter. However, it is interesting to note that the highest temperature value $\left(21.38^{\circ} \mathrm{C}\right.$ as a mean) was reached in October 1997 at the three stations. This figure was higher than the mean value calculated for the autumn peri-

TABLE 2. - Seasonal mean values of the environmental variables measured during the study period. These means were compared with a oneway ANOVA followed by a Tukey test. The asterisk indicates significant differences at $\mathrm{p}=0.01$. Units: temperature, ${ }^{\circ} \mathrm{C}$; salinity, PSU; mixed depth, m; nutrients, $\mu \mathrm{M}$; Chl $a, \mu \mathrm{g} \mathrm{l}^{-1}$; cell abundance, cell $\mathrm{ml}^{-1}$.

\begin{tabular}{|c|c|c|c|c|c|}
\hline Variable & Spring & Summer & Fall & Winter & $\mathrm{P}$ \\
\hline Temperature & $16.25 \pm 1.01 *$ & $19.45 \pm 1.44 * *$ & $18.72 \pm 1.52 * * *$ & $15.48 \pm 1.19 *$ & 0.000 \\
\hline Salinity & $37.32 \pm 0.25$ & $37.07 \pm 0.24$ & $36.77 \pm 0.17 *$ & $37.12 \pm 0.36$ & 0.000 \\
\hline Mixed depth & $9.3 \pm 4.4$ & $8.5 \pm 5.8$ & $8.7 \pm 2.8$ & $17.6 \pm 7.8 *$ & 0.000 \\
\hline Nitrate+Nitrite & $0.75 \pm 0.86$ & $0.53 \pm 0.59$ & $0.65 \pm 1.02$ & $1.66 \pm 1.93$ & 0.107 \\
\hline Phosphate & $0.12 \pm 0.08$ & $0.11 \pm 0.07$ & $0.12 \pm 0.08$ & $0.17 \pm 0.09$ & 0.280 \\
\hline Silicate & $1.07 \pm 1.02$ & $0.90 \pm 0.43$ & $0.93 \pm 0.56$ & $2.01 \pm 0.90 *$ & 0.003 \\
\hline $\mathrm{N}: \mathrm{P}$ molar ratio & $12.60 \pm 0.33$ & $13.02 \pm 1.64$ & $10.32 \pm 0.78$ & $11.33 \pm 0.91$ & 0.952 \\
\hline N:Si molar ratio & $0.92 \pm 0.01$ & $1.70 \pm 0.25$ & $1.06 \pm 0.08$ & $1.01 \pm 0.09$ & 0.284 \\
\hline Si:P molar ratio & $10.5 \pm 0.90$ & $9.8 \pm 0.74$ & $11.2 \pm 0.70$ & $13.0 \pm 0.86$ & 0.641 \\
\hline Chl a & $1.79 \pm 1.71 * *$ & $0.99 \pm 0.91 *$ & $0.85 \pm 1.02 *$ & $0.83 \pm 0.66^{*}$ & 0.000 \\
\hline Cell abundance & $457 \pm 643 * *$ & $173 \pm 210 *$ & $223 \pm 184 *$ & $180 \pm 155^{*}$ & 0.009 \\
\hline
\end{tabular}


od. Therefore, it can be concluded that the 1997 autumn was unusually warm. Although an ANOVA was statistically significant for salinity, the post-hoc comparison of means revealed that the only significant differences were during autumn. Mixed layer depth also followed a seasonal cycle and was higher during winter. Nitrate plus nitrite and phosphate concentrations were subjected to wide variations during the entire time period analysed. Thus, nitrate plus nitrite ranged from 6.2 to $0.1 \mu \mathrm{M}$ and phosphate from 0.4 to $0.02 \mu \mathrm{M}$. However, their concentrations did not vary homogenously through the seasonal cycle although they tended to be higher during winter. In contrast, the silicate concentration followed a seasonal cycle, with concentrations significantly higher in winter. Statistically non-significant differences were obtained when the nutrient molar ratios were compared seasonally.

The mean concentration of chlorophyll $a$ in the upper seawater layer (up $50 \mathrm{~m}$ depth) ranged from 0.05 to $4.30 \mu \mathrm{g} \mathrm{l}^{-1}$ during the study period. There was a significant correlation between chlorophyll $a$ concentration and cell abundance $\left(\mathrm{R}^{2}=0.49, \mathrm{P}<\right.$ 0.000 ), which indicates that the micro- and nanophytoplankton fractions made up most of the phytoplankton biomass (it should be noted that pico-phytoplankton was not determined in this study). Both variables (chlorophyll $a$ and cell abundance) followed a seasonal cycle (Table 2), and the higher values were obtained in the spring period. However, this averaged seasonal pattern was often missed since a phytoplankton spring bloom was only detected in 4 out of the 8 complete seasonal cycles analysed. For the other annual cycles, the chlorophyll $a$ and cell abundance peaks appeared to be absent or displaced temporally. In spite of the wide variation range of the environmental variables, the correspondence analysis performed to compare the changes in the phytoplankton community structure with the hydrological and chemical variables listed in Table 2 (excluding the mixed depth) was non-significant $(\mathrm{P}>0.05)$. The particular values of the variables in each sample were used for this analysis.

The year-to-year change patterns in the nutrient concentrations were analysed independently. Figure 8 shows the integrated concentrations of nitrate plus nitrite, phosphate and silicate for the study area (note that there are no available data for some seasons in 2000 and 2001). The concentration of the three nutrients sharply decreased from 1995 to 1998 , when the lowest values were reached. They then increased in 1999 although the silicate increase was
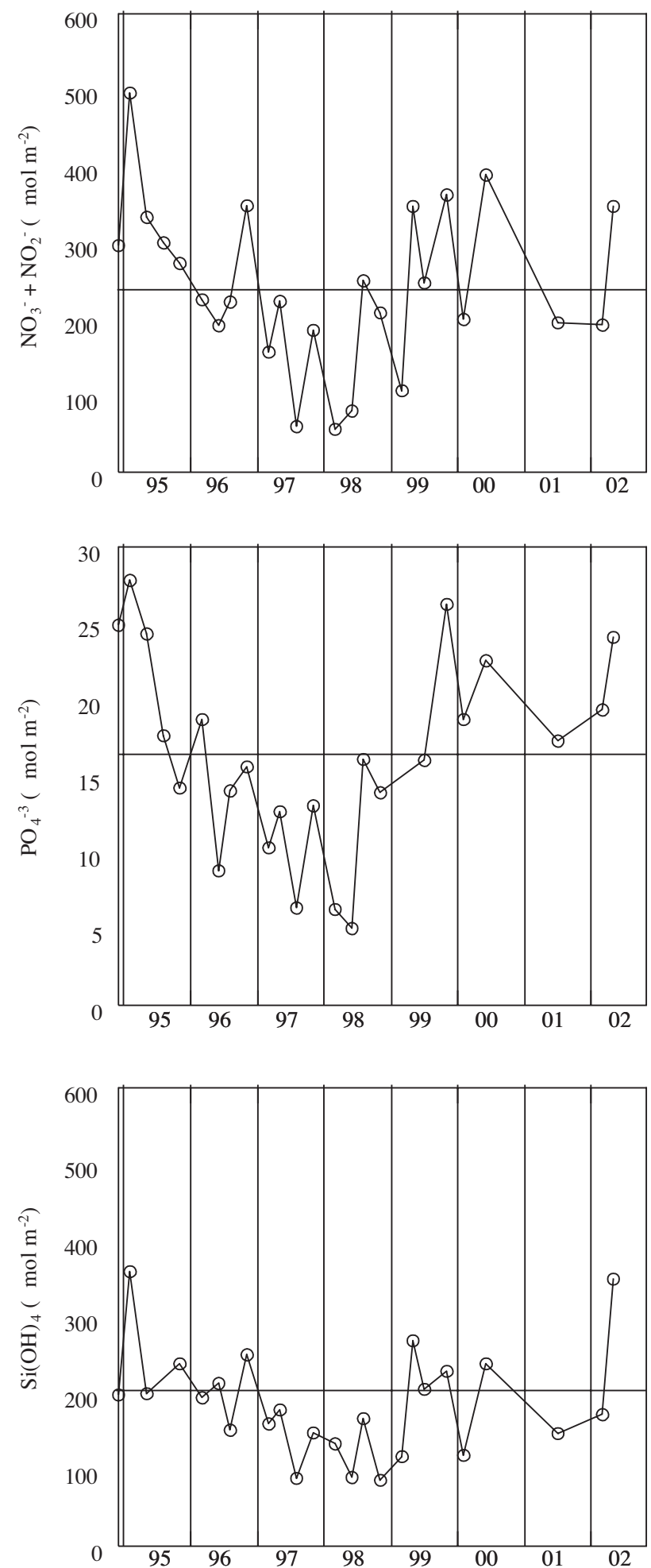

FIG. 8. - Nutrient concentration mean for the study area. Each point represents the integrated value from the surface to $75 \mathrm{~m}$ depth. The horizontal lines indicate the mean values for the entire study time period. Note that data were not available for some surveys performed in 2000 and 2001.

proportionally lower than the increase in nitrogen and phosphate. It should be noted that a decrease in the nutrient concentration was also produced in 

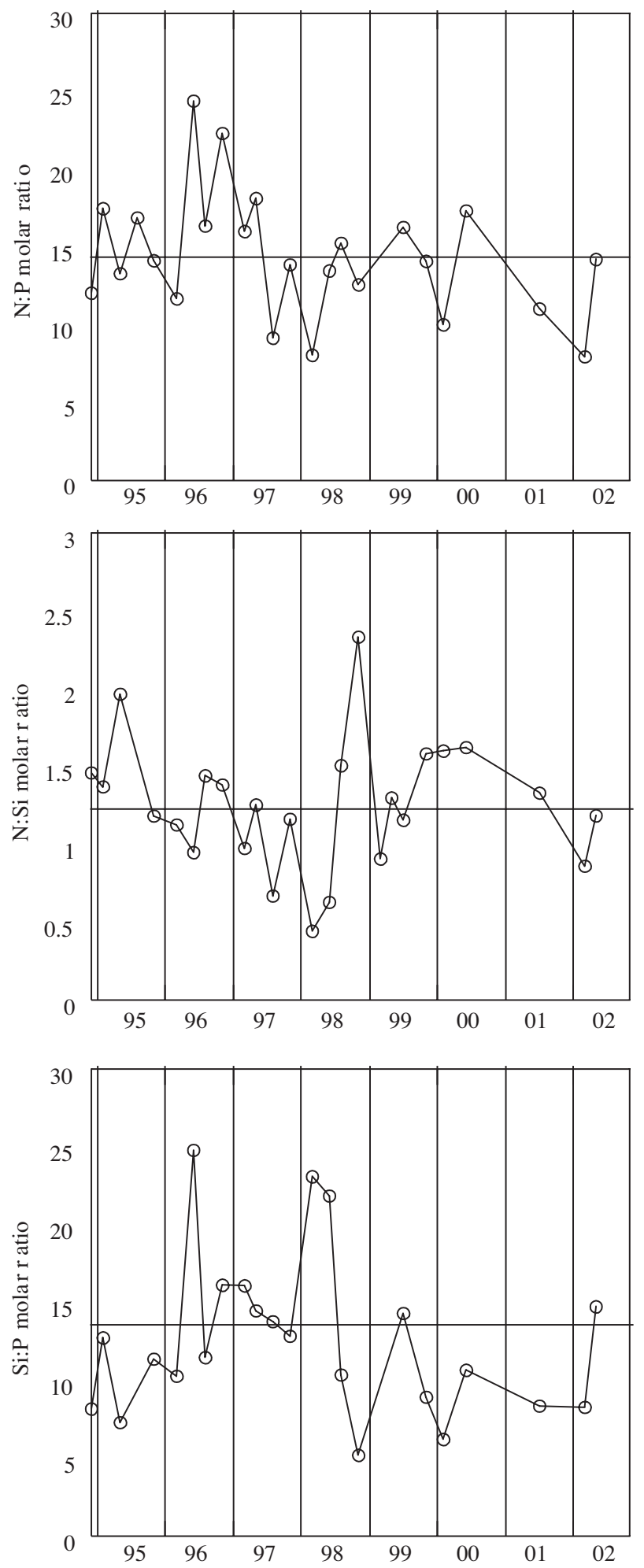

FIG. 9. - N:Si, N:P and Si:P molar ratio means for the study area. Each point represents the average value from the surface to $75 \mathrm{~m}$ depth. The horizontal lines indicate the mean values for the entire study time period. Note that data were not available for some surveys performed in 2000 and 2001.

2001. On average, the N:P, Si:P and N:Si molar ratios $(14.3,13.5$ and 1.2 respectively) were close to the theoretical Redfield ratios (16:1 for N:P and Si:P ratios and 1:1 for $\mathrm{N}: \mathrm{Si}$ ratio). However, they were highly variable throughout the study period (Fig. 9) and some change patterns could be distinguished. The highest values of the N:P ratio were obtained in 1996. In contrast, ratios that were much lower than Redfield ratio values were frequently reached from 1998 to 2002. The N:Si ratio decreased sharply from 1995 to spring 1998 . Then, it increased significantly until spring 2000. The highest value of this ratio (2.3) was reached in autumn 1998. The mean Si:P molar ratio peaked over the Redfield ratio value on several occasions from 1996 to spring 1998. However, lower values were obtained from summer 1998 to 2002, when the mean Si:P ratio was only 9.8. It was significantly lower than the mean $\mathrm{Si}: \mathrm{P}$ ratio obtained previously $(16.0 ; \mathrm{P}=0.02)$

\section{DISCUSSION}

The phytoplankton abundance reported in this study averaged 200 cells ml-1. This value is high in comparison with values described in the literature for other adjacent areas. Videau et al. (1994), published phytoplankton abundance (for the micro- and pico-plankton size fractions) ranging from 5 to 25 cells ml-1 in the Almería-Oran geostrophic front system, which were similar to figures published for some eastern Mediterranean basins (Polat, 2002). The high phytoplanktonic abundance found on the north-western coast of the Alborán Sea has been referred to previously. Margalef (1969), registered high values of phytoplankton in a transect situated off the Málaga coast in the summer of 1968. In this area, Delgado (1990) also reported a mean abundance of 21 and 257 cells ml ${ }^{-1}$ in two surveys performed in January and April 1982 respectively. These data are in accordance with the values of chlorophyll $a$ concentration published for the Alborán Sea which define a well delimited phytoplankton enriched patch in its north-western part (Arias, 1975; Cortés et al., 1985; Rodríguez et al., 1997; Gómez et al., 2000). There is less published data on the taxonomic structure of the communities. Delgado (1990) described a community dominated by small-flagellates and diatoms with a low abundance of dinoflagellates (lower than 2 cells $\mathrm{ml}^{-1}$ ). Balle (1960), stated that diatoms dominated the whole Alborán Sea. However, in this report, significant changes in phytoplankton taxonomic composition were demonstrated by a SDA and cluster analysis. Although small flagellates and diatoms were 
dominant for much of the study period, phytoplankton communities were dominated by coccolitophorids for some years and even occasionally by dinoflagellates. According to the species-oriented cluster analyses, two well-differentiated communities appeared during the study period. One community (separated in the branch I of CA) included species which were dominant at station 1 from 1994 to 1997 (L. danicus, P. pungens, T. decipiens). This community was mainly composed of chain-forming pennate diatoms belonging to the genus Pseudonitzschia and the centric diatoms Thalasiossira, Rhizosolenia, Lectocylindrus and Skeletonema. Dinoflagellates belonging to the species Scrippsiella trochoidea, Protoperidinium depressum and Prorocentrum minimum were also frequent. This community is similar to the one described by Delgado (1990), in his survey in 1988. The second community (branch II of CA) was characterized by the coccolitophorids Calcidiscus and Gephyrocapsa and the dinoflagellates Prorocentrum compressum, Ceratium extensum and Ceratium furca. Some of the species classified in this cluster (i.e. Gephyrocapsa sp.) were dominant during 2000-2002 at the three stations. It is interesting to note that the mean phytoplankton cell abundance in the samples dominated by the species in this community was only 15 cells $\mathrm{ml}^{-1}$. In contrast, higher abundances were linked to the dominance of diatoms included in branch I. The third branch of CA (III) included Emiliania huxleyi and unidentified small flagellates. E. huxleyi appeared for much of the study period (in fact, it was the most frequent species) and therefore it can be concluded that the species combination separated in branch III did not characterize any community. The results of the CA compare very well with the sample-oriented analysis performed using the SDA. Thus, the two communities were segregated temporally: the diatom-dominated community was present until 1999 while the coccolitophorid-dominated community was present mainly from 2000 to 2002 . The SDA separated the samples belonging to these two periods into two clusters along the x-axis. Interestingly, the 19951999 year group was segregated along the $y$-axis because the years 1995, 1996 and 1997 were positively correlated to this axis and 1998 and 1999 were negatively correlated. The statistical results indicate that a shift from a diatom-dominated community to a coccolitophorid-dominated one occurred in 2000. From a qualitative point of view, this shift was linked to the increase in Gephyrocapsa and the unidentified small flagellate group almost disappearing (mean abundance of the unidentified small flagellates dropped to 2.4 cells ml-1 as compared to 95 cells ml${ }^{1}$ found previously). Additionally, significant changes were produced in the diatom-dominated community from 1997 to 1998 . This change was mainly characterized by the strong increase in the coccolitophorid Emiliania huxleyi, which reached its highest abundance during 1998.

An annual hydrological cycle for the north-western Alborán sea can be described from our data. The water column was stratified for much of the cycle since the mixed layer depth calculated from $\mathrm{s}_{\mathrm{T}}$ values remained roughly constant. However, the mixed layer depth increased in winter due to the decrease in the surface temperature, which indicates that there was de-stratification of the water column. The annual change pattern of the phytoplankton biomass (as estimated from both the chlorophyll $a$ and cell abundances) appears to be linked to this hydrological cycle, since it generally increased in the spring period, which coincides with the initial phase of the stratification period. These results compare well with the phytoplankton seasonal dynamic described for the Alborán sea as a whole, which was inferred from chlorophyll $a$ concentration changes (GarcíaGórriz, 2001). The higher values of chlorophyll $a$ in spring are probably a consequence of the nutrient enrichment produced in the euphotic layer during winter, following the de-stratification period. However, this enrichment was only significant for the silicate concentration, since there was no seasonal cycle for the nitrate plus nitrite or phosphate concentrations. As mentioned above, the stations sampled were situated in areas where nutrients are upwelled by vertical turbulence fuelled by the geostrophic front associated with the Atlantic seawater jet coming in through the Gibraltar Strait (Sharhan et al., 2000). Additionally, several nonperiodic mechanisms intensify this upwelling: (1) Ekman transport driven by winds (Sharhan et al., 2000); (2) cyclonic eddies due to filaments derived from the main Atlantic current (Parrilla and Kinder, 1987; Cano and García, 1991); and (3) internal wave breaking (García Lafuente and Cano, 1994), which is produced by Atlantic tide currents. An increase in salinity in the surface layer is a good indicator of the upwelling of deeper Mediterranean water which is characterized by higher salinity and nutrient concentration in comparison with the surface Atlantic seawater. According to our seasonal data of salinity and mixed layer depth, nutrient supply to the euphotic 
layer could continue even during the time period with the strongest thermal stratification. Therefore, the effect of the hydrological cycle on the nutrient concentration could often be masked by these nonperiodic events. In fact, often the mean annual pattern of chlorophyll $a$ and cell abundance did not occur during the study period, since the spring peak was only obtained in 4 out of 8 complete cycles analysed. The influence of the non-periodic changes could also explain the absence of a detectable seasonal sucessional pattern for the phytoplankton communities, in spite of the one described for chlorophyll $a$ or cell abundance.

From our results, it can be seen that the interannual variability of the phytoplankton communities was more significant than the seasonal variability. This was demonstrated by the SDA performed with the samples grouped into seasonal periods. The results from this analysis compare well with the results from other papers which demonstrate that inter-annual variations in phytoplankton are often large (Holling et al., 1981; Solic et al., 1997; Karentz and Smayda, 1998; Yallop, 2001). It is generally accepted that changes in the nutrient regime are responsible for shifts in the phytoplankton communities. In particular, it has been suggested that an increase in phosphate and nitrate in relation to silicate concentrations could produce a shift from diatom-dominated ecosystems to non-siliceous algal dominated ones (Bethoux et al., 2002). Our data indicate that the inter-annual changes of the phytoplankton taxonomic composition could be related to the year-to-year change patterns in nutrient concentration. The peaks of phytoplankton cells occurred during yearly periods (1995 and 1999) with nutrient concentrations higher than the mean value obtained for the entire study period. Three time periods can be described with respect to nutrient concentrations: a sharp decrease from 1995 to 1997, then a continuous increase from 1998 to 1999 and then in the 2000-2001 period the nutrients stayed roughly constant. It should be noted that the variation range for $\mathrm{Si}$ concentration was lower than the variation range of $\mathrm{N}$ and $\mathrm{P}$. As a consequence, the $\mathrm{N}: \mathrm{Si}$ ratio tended to decrease and the Si:P ratio tended to increase from 1995 to 1998 . The temporal distribution of the two phytoplankton communities identified by the CA matched the nutrient change patterns. Thus the diatom community (branch I) was dominant in the time period during which the $\mathrm{N}: \mathrm{Si}$ and $\mathrm{Si}: \mathrm{P}$ ratios indicated an excess of $\mathrm{Si}$ with respect to $\mathrm{N}$ and $\mathrm{P}$, which is the appropriate nutrient conditions for diatom proliferation. The Si:P ratio was much lower than $16: 1$ in 2000-2002, which could indicate that diatom growth was limited by $\mathrm{Si}$ with respect to $\mathrm{P}$. This favours non-siliceous phytoplankton dominating the community, which did in fact occur during this period. Interestingly, the lower values of nutrient concentrations were reached in 1997-1998, when another shift in the phytoplankton communities occurred according to the SDA.

Although the relationship between the nutrient regime and the phytoplankton community composition appears evident according to our data, other factors could also contribute to the changes observed. Thus, Van Beusekom and Weber (1992), and Dippner (1998), proposed that the decreased diatom abundance could be affected by an aluminium-mediated delay of the silica remineralization. In contrast, Holligan et al. (1981), and Yallop et al. (2001), indicated that vertical stability of the water column is the most significant environmental variable that determines the relative abundance of dinoflagellates and diatoms. Karentz and Smayda (1998), and Macedo et al. (2001), concluded that grazing can be of major importance for species succession if there is selective grazing on one particular phytoplanktonic group. According to Banse (1992), the nano-sized phytoplankton biomass is probably controlled by micrograzers.

The reasons for the inter-annual changes in the nutrient regime cannot be fully cleared up by our data. However, it should be noted that these change patterns were not found when the integrated values for the $50 \mathrm{~m}$ - or $20 \mathrm{~m}$-upper seawater layer were analysed (data not shown). The interface between Atlantic and Mediterranean seawater is generally located at 40-70 $\mathrm{m}$ depth in the study area (Fernández, 1988), therefore it is reasonable to think that the nutrient concentration integrated value from the surface to $75 \mathrm{~m}$ depth must be strongly influenced by the characteristics of the Mediterranean seawater which is potentially upwelled. On the another hand, Dafner et al. (2003), demonstrated that the surface Atlantic water which enters the Gibraltar Strait is depleted in nutrients and has a N:P ratio lower than 16:1. In contrast, Bethoux et al. (2002), reported that Mediterranean seawater has high N:P and Si:P ratios, suggesting a deficiency of $\mathrm{P}$ in relation to $\mathrm{N}$ and $\mathrm{Si}$. Therefore, the year-to-year change patterns in nutrients could be due to modifications in the upwelling intensity which injects rich nutrient waters into the surface layer. Since no nutrient seasonal cycle was found, these changes must be more 
significant than the fertilization effect of the surface water produced in the annual de-stratification period. Interestingly, the surface temperature in October 1997 was abnormally high, which could indicate a smoothing of the upwelling, which is in accordance with the low nutrient concentration values found for this period. In conclusion, the inter-annual changes could be connected to general patterns of change in: (1) climatic events (frequency and intensity of the local winds) and/or (2) the seawater circulation through the Strait of Gibraltar. Climatic and hydrological data for the entire Alborán basin must be analysed to test this hypothesis.

\section{ACKNOWLEDGEMENTS}

This work has been funded by the Projects ECOMÁLAGA (Instituto Español de Oceanografía, IEO), ECOFITO (IEO) and NORALBORÁN (Ministerio Español de Ciencia y Tecnología, MCYT). JM Mercado is supported by a contract within the Ramón y Cajal Programme of the MCYT. We thank the crew of the RV "Odón de Buen" for their invaluable help at sea.

\section{REFERENCES}

Allen, T.F.H. and S. Skagen. - 1973. Multivariate geometry as an approach to algal community analysis. Br. Phycol. J., 8: 267287.

Arias, E. - 1975. Pigmentos y producción primaria de la campaña MAROC_IBERIA 1. Res. Exp. Cient. B. O. Cornide, 4: 101111.

Balle, P. - 1963. Phytoplancton de la Mer d'Alboran et du Golfe de Cádiz. Conseil International pour l'Exploration de la Mer, 105.

Banse, K. -1992. Grazing, temporal changes of phytoplankton concentrations, and the microbial loop in the open sea. In: P.G. Falkowski and A.D. Woodhead (eds.), Primary productivity and biochemical cycles in the sea, pp. 409-440. Plenum Press, New York.

Bethoux, J.P., Morin, P. and D.P. Ruíz-Pino. - 2002. Temporal trends in nutrients ratios: chemical evidence of Mediterranean ecosystem changes driven by human activity. Deep-sea Res. Part II, 49: 2007-2016.

Camiñas, J.A., Cano, N., Cortés, D., Díaz del Río, V., García, A. and J.P. Rubín. - 1998. "Ecomálaga": an ecosystem analysis of the Mediterranean coast around Málaga, Spain. J. Coast. Conserv., 4: 43-50.

Cano, N. and J. García. - 1991. Corrientes en el litoral malagueño. Bol. Inst. Esp. Oceanogr. 7: 59-77.

Cohen, A.L. - 1974. Critical point drying. In A.M. Hyat (ed.) Principles and techniques of Scanning Electronic Microscope 1. Van-Nostrand-Reinhold, New York, 44-112.

Claustre H., P. Kerhervé, J.C. Marty, L. Prieur, C. Videau and J.-HHecq. - 1994. Phytoplankton dynamics associated with a geostrophic front: Ecological and biogeochemical implications. J. Mar. Syst., 52: 711-742.

Cooley, W.W. and P.R. Lohnes. - 1971. Multivariate Data Analysis. Wiley \& Sons, New York.

Cortés, D.R., J. Gil and A. García. - 1985. General distribution of chlorophyll, temperature and salinity in the north-western sector of Alboran Sea. Communication from the XXIX Congres-
Assemblee pleniere CIESM. Lucerne, 11-19.

Dafner, E.V., R. Boscolo and H.L. Bryden. - 2003. The N:Si:P molar ratio in the Strait of Gibraltar. Geophys. Res. Lett., 30: 1506/doi 10.1029/2002GL016274.

Delgado, M. - 1990. Phytoplankton distribution along the Spanish coast of the Alboran Sea. Sci. Mar., 54: 169-178.

Dippner, J.W. - 1998. Competition between different groups of phytoplankton for nutrients in the southern North Sea. J. Mar. Syst., 14: 181-198.

Echevarría, F., J.G. Lafuente, J.G. Bruno, G. Gorsky, M. Goutx, N. González, C.M. García, F. Gómez, J.M. Vargas, M. Picheral, L. Striby, M. Varela, J.J. Alonso, A. Reul, A. Cozar, L. Prieto, T. Sharhan, F. Plaza and F. Jiménez-Gómez. - 2002. Physical-biological coupling in the Strait of Gibraltar. Deep-Sea Res. II, 49: 4115-4130.

Fernández, J.G. - 1988. Variación estacional del espesor de la capa de agua de procedencia atlántica y la formación del agua de invierno en la costa sur-occidental mediterránea. Inf. Tec. Inst. Esp. Oceanogr., 56: 1-16.

Fiala, M., A. Sournia, H. Claustre, J.-C. Mart, L. Prieur and G. Vétion. - 1994. Gradients of phytoplankton abundance, composition and photosynthetic pigments across the Almería-Orán front (SW Mediterranean Sea). J. Mar. Syst. 5: 223-233.

García-Górriz, E. and M.-E. Carr. - 2001. Physical control of phytoplankton distributions in the Alboran Sea: A numerical and satellite approach. J. Geophys. Res., 106: 16795-16805.

García-Lafuente, J. and N. Cano. - 1994. Tidal dynamics and associated features of the northwestern shelf of the Alborán Sea. Cont. Shelf Res., 14: 1-21.

Gómez, F., N. González, F. Echevarría. and C.M. García. - 2000. Distribution and fluxes of disolved nutrients in the Strait of Gibraltar and its relationships to microphytoplankton biomass. Estuar. Coast. Shelf Sci., 51: 439-449.

Holligan, P.M, Maddock, L. and D.J. Dodge. -1980 . The distribution of dinoflagellates around the British Isles in July 1977: a multivariate analysis. J. Mar. Biol. Assoc. UK., 60: 851-867.

Jacquet, S., L. Prieur, C. Avois-Jacquet, J.-F. Lennon and D. Vaulot. - 2002. Short-timescale variability of picophytoplankton abundance and cellular parameters in surface waters of the Alborán Sea (western Mediterranean). J. Plantkon Res., 24: 635-651.

Karentz, D. and T.S. Smayda. - 1998. Temporal patterns and variations in phytoplankton community organization and abundance in Narragansett Bay during 1959-1980. J. Plankton Res., 20: $145-168$.

Margalef, R. - 1969. Small scale distribution of phytoplankton in Western Mediterranean at the end of July. Pubbl. Staz. Zool. Napoli, 37: 40-61.

Marty, J.-C., J. Ciaverini, M.-D. Pizay and B. Avril. - 2002. Seasonal and interannual dynamics of nutrients and phytoplankton pigments in the western Mediterranean Sea at the DYFAMED time-series station (1991-1999). Deep-Sea Res. II, 49: 1965-1985.

Macedo, M.F., P. Duarte, P. Mendes and J.G. Ferreira. - 2001. Annual variation of enviromental variables, phytoplankton species composition and photosynthesis parameters in a coastal lagoon. J. Plankton Res., 23: 719-732.

Minas, H.J., B. Coste, P. LeCorre, M. Minas and P. Raimbault -1991 . Biological and geochemical signatures associated with the water circulation through the Strait of Gibraltar and in western Alboran Sea. J. Geophys. Res., 96: 8755-8771.

Moncheva, S., O. Gotsis-Skretas, K. Pagou and A. Krastev. - 2001. Mediterranean coastal ecosystems subjected to anthropogenic eutrophication: similarities and differences. Est. Coast. Shelf Sci., 53: 281-295.

Parrilla, G. and T.H. Kinder. - 1987. Oceanografía física del Mar de Alborán. Bol. Inst. Esp. Oceanogr., 4(1): 133-165.

Polat, S. - 2002. Nutrients, chlorophyll a and phytoplankton in the Iskenderun Bay (Northeastern Mediterranean). Mar. Ecol., 23: $115-126$.

Reul, A., J.M. Vargas, F. Jiménez-Gómez, F. Echevarría, J. GarcíaLafuente and J. Rodríguez. - 2002. Exchange of planktonic biomass through the Strait of Gibraltar in late summer conditions. Deep-Sea Res. II, 49: 4131-4144

Rodríguez, V., J.M. Blanco, F. Jiménez-Gómez, J. Rodríguez, F Echevarría and F. Guerrero. - 1997. Distribución espacial de algunos estimadores de biomasa fitoplanctónica y material orgánico particulado en el mar de Alborán, en condiciones de 
estratificación térmica (julio de 1993). Publ. Espec. Inst. Esp. Oceanogr., 24: 53-64.

Ros, M. and M.R. Miracle. - 1984. Distribución temporal de las dinoflageladas del Mar Menor. Anal. Biol., 2: 169-180.

SCOR-UNESCO. - 1966. Determination of photosynthetic pigments in sea-water. Report of Working Group 17. Monographs on oceanographic methodology, $\mathrm{n}^{\circ} 1$. UNESCO, París

Sharhan, T., J. GarcíaLafuente, M. Vargas, J.M. Vargas and P. Plaza. - 2000. Upwelling mechanisms in the northwestern Alborán Sea. J. Mar. Syst., 23: 317-331.

Sokal, P.R. and F.J. Rohlf - 1981. Biometry, $2^{\text {nd }}$ edn. W.H. Freeman, San Francisco, CA.

Solic, M., N. Krstulovic, I. Marasovic, A. Baranovic, T. PucherPetrovic and T. Vicetic. - 1997. Analysis of time series of plankton communities in the Adriatic Sea: distinguishing between natural and man-induced changes. Oceanol. Acta, 20: 131-143.

Ter Braak, C. J. and I.C. Prenctice. - 1988. A theory of gradient analysis. Adv. Ecol. Res., 18: 271-317.

Tomas, C.R. - 1997. Identifying Marine Phytoplankton. Academic Press Limited, London.

Turley, C.M. - 1999. The changing Mediaterranean Sea-a sensitive ecosystem. Prog. Oceanogr., 44: 387-400.

UNESCO. - 1988. Eutrophication in the Mediterranean Sea: receiving capacity and monitoring of long term effects. UNESCO Rep. Mar. Sci., 49, 195 p.
Utermöhl, H. - 1958. Zur Vervollkommnung der quantitativen Phytoplankton-Methodik. Mitt. int Verein. Limnol., 9: 1-38.

Van de Beusekom, J.E.E. and A. Webe.r - 1992. Decreasing diatom abundance in the North Sea: the possible significance of aluminium. In: G. Colombo et al. (eds.) Marine Eutrophication and Population Dynamics, pp. 121-127. Olsen and Olsen, Fredensborg.

Vargas-Yáñez, M., T. Ramírez, D. Cortés, M. Sebastián and P. Plaza. - 2002. Warming trends in the continental shelf of Málaga Bay (Alborán Sea). Geophy. Res. Lett., 29 (22): 2082, doi:10.1029/2002GL015306.

Videau, C., A. Sournia, L. Prieur and M. Fiala. - 1994. Phytoplankton and primary production characteristics at selected sites in the geostrophic Almeria-Oran front system (SW Mediterranean Sea). J. Mar. Syst., 5: 235-250.

Vidussi, F., H. Claustre, B.B. Manca, A. Luchetta and J.-C. Marty. - 2001. Phytoplankton pigment distribution in relation to upper thermocline circulation in the eastern Mediterranean Sea during winter. J. Geophys. Res.(C Oceans), 106: 19939-19956.

Ward, J. H. - 1963. Hierarchical grouping to optimize an objective function. J. Am. Stat. Ass., 58: 236.

Yallop, M.L. - 2001. Distribution patterns and biomass estimates of diatoms and autotrophic dinoflagellates in the NE Atlantic during June and July 1996. Deep-sea Res. Part II, 48: 825-844.

Scient. ed.: J. Rodríguez 
